\title{
KETERKAITAN KEPEMILIKAN MANAJERIAL, INSTITUSIONAL, DAN KOMITE AUDIT PADA NILAI PERUSAHAAN DI MEDIASI OLEH KUALITAS LABA
}

\author{
YUSUP HARI SUBAGYA
}

Sekolah Tinggi Ilmu Ekonomi St. Pignatelli Surakarta

Email: yusup.hari@gmail.com

\begin{abstract}
Abstrak
Penelitian ini bertujuan untuk mengetahui pengaruh mekanisme corporate governance terhadap nilai perusahaan dengan kualitas laba sebagai variabel mediasi. Mekanisme corporate governance menggunakan tiga variabel yaitu kepemilikan manajerial, kepemilikan institusional, dan komite audit.

Pengukuran Kualitas laba menggunakan proksi Earnings Response Coefficient (ERC) dan untuk nilai perusahaan menggunakan Price Book Value (PBV). Penelitian ini menggunakan data empiris dari Bursa Efek Indonesia dengan sampel sebanyak 34 perusahaan untuk periode 2012 -2014. Metode penelitian yang digunakan adalah regresi berganda.

Hasil penelitian ini adalah Kualitas laba sebagai variabel yang mediasi antara komite audit dengan nilai perusahaan. Dan tidak memediasi kepemilikan manajerial, institusional pada nilai perusahaan.
\end{abstract}

Kata kunci: Kepemilikan Manajerial, Institusional, Komite Audit, Kualitas Laba, Nilai Perusahaan.

\section{PENDAHULUAN}

Kepemilikan saham oleh manajer, diharapkan manajer akan bertindak sesuai dengan keinginan principal karena manajer akan termotivasi untuk meningkatkan kinerja. Kepemilikan institusional memiliki kemampuan untuk mengendalikan pihak manajemen melalui proses monitoring secara efektif sehingga mengurangi tindakan manajemen melakukan manajemen laba. Selain itu, keberadaan dewan komisaris dan komite audit diharapkan dapat meningkatkan nilai tambah bagiperusahaan dengan membatasi tingkat manajemen laba melalui fungsi pengawasan atas pelaporan keuangan. (Siallagan dan Machfoedz, 2006).

Tumirin (2007); Oktorina Megawati, Linda Kusumaning Wedari, (2015) menyatakan adanya penerapan GCG (kepemilikan manajerial, institusional, dan komite audit) akan mempengaruhi tercapainya nilai perusahaan. Perusahaan tentunya harus memastikan kepada para penanam modal bahwa dana yang mereka tanamkan untuk kegiatan pembiayaan, investasi, dan pertumbuhan perusahaan digunakan secara tepat dan seefisien mungkin serta memastikan bahwa manajemen bertindak terbaik untuk kepentingan perusahaan. Dengan adanya salah satu mekanisme GCG diharapkan monitoring terhadap manajer perusahaan dapat lebih efektif sehingga dapat meningkatkan kinerja perusahaan dan nilai perusahaan. Jadi jika perusahaan menerapkan sistem GCG diharapkan kinerja tersebut akan meningkat menjadi lebih baik, 
dengan meningkatnya kinerja perusahaan diharapkan juga dapat meningkatkan harga saham perusahaan sebagai indikator dari nilai perusahaan sehingga nilai perusahaan akan meningkat.

Riyanto (2005); Febriani Hanna Amilia, Murni Sri (2014), mengemukakan bahwa corporate governance yang efektif dalam jangka panjang dapat meningkatkan kinerja perusahaan dan menguntungkan pemegang saham. Secara teoritis praktek GCG dapat meningkatkan nilai perusahaan diantaranya meningkatkan kinerja keuangan, mengurangi resiko yang merugikan akibat tindakan pengelola yang cenderung menguntungkan diri sendiri dan umumnya GCG dapat meningkatkan kepercayaan investor.

Praktik Corporate Governance (Kepemilikan Manajerial, Institusional, dan Komite Audit) yang baik mempengaruhi kualitas laporan keuangan yang menjadi salah satu sorotan para pemangku kepentingan (stakeholder's). Laporan keuangan yang baik salah satunya dapat mencerminkan keadaan yang sesungguhnya dari sebuah perusahaan. Dan informasi ini juga diharapkan menjadi pedoman untuk pemegang saham dan investor potensial untuk menentukan kepentingan investasi mereka terhadap saham emiten.(Frysa, 2011)

Salah satu informasi yang terdapat di dalam laporan keuangan adalah informasi mengenai laba perusahaan. Bagi pemilik saham dan investor, laba berarti peningkatan nilai ekonomis (wealth) yang akan diterima, melalui pembagian dividen. Laba juga digunakan sebagai alat untuk mengukur kinerja manajemen perusahaan selama periode tertentu yang pada umumnya menjadi perhatian pihak-pihak tertentu terutama dalam menaksir kinerja atas pertanggungjawaban manajemen dalam pengelolaan sumber daya yang dipercayakan kepada mereka, serta dapat dipergunakan untuk memperkirakan prospeknya di masa depan.(IAI, 2004)

Dari beberapa informasi yang diperoleh di laporan keuangan, biasanya laba menjadi pusat perhatian pihak pemakai. Laba yang dipublikasikan dapat memberikan respon yang bervariasi, yang menunjukkan adanya reaksi pasar terhadap informasi laba reaksi yang diberikan tergantung dari kualitas laba yang dihasilkan oleh perusahaan. Dengan kata lain, laba yang dilaporkan memiliki kekuatan respon (power of response). Kuatnya reaksi pasar terhadap informasi laba yang tercermin dari tingginya ERC, menunjukkan laba yang dilaporkan berkualitas. Demikian sebaliknya, lemahnya reaksi pasar terhadap informasi laba yang tercermin dari rendahnya ERC, menunjukkan laba yang dilaporkan kurang atau tidak berkualitas.(Boediono, 2005; Febriani H.A. dan Murni. S., 2014).

Kualitas laba ini diduga dipengaruhi oleh adanya manajemen laba dan mekanisme Corporate Governance dalam hal ini yaitu mekanisme kepemilikan institusional, kepemilikan manajerial dan komposisi dewan komisaris. Rendahnya kualitas laba diduga disebabkan karena lemahnya penerapan Corporate Governance, sedangkan ciri utama dari lemahnya Corporate governance sendiri adalah adanya tindakan mementingkan diri sendiri yang dilakukan pihak manajer perusahaan. (Darmawati, 2004)

Dalam penelitian ini peneliti menggunakan tiga mekanisme dari Good Corporate Governance yaitu kepemilikan manajerial, kepemilikan institusional dan komite audit. Dewan Komisaris tidak menjadi acuan dalam penelitian ini dikarenakan fungsi dari dewan komisaris pada perusahaan manufaktur yang menjadi sampel penelitian tidak memennuhi proporsi yang diwajibkan oleh KNKG (2006) pada perusahaan yang seharusnya. Penelitian ini mengambil sampel pada perusahaan manufaktur agar dapat memperlihatkan keadaan 
terkini yang notabene lebih dari $50 \%$ perusahaan manufaktur berkontribusi pada perekonomian Indonesia.

\section{RUMUSAN MASALAH}

Berdasarkan latar belakang yang telah diuraikan maka rumusan masalah dalam penelitian ini adalah: Apakah kualitas laba menjadi variable mediasi antara kepemilikan manajerial, kepemilikan institusional, dan komite audit terhadap nilai perusahaan?

\section{TEORI DAN PENGEMBANGAN HIPOTESIS}

Kepemilikan manajerial yaitu kepemilikan saham oleh manajemen yang secara aktif ikut mengambil keputusan perusahaan. Kepemilikan manajerial diharapkan dapat menyelaraskan potensi perbedaan kepentingan antara pemegang saham luar dengan manajemen (Jansen dan Meckling, 1976).Kepemilikan saham tersebut dapat diperoleh jika perusahaan menerapkan program kepemilikan saham yang dikenal dengan nama Program Kepemilikan Saham oleh Karyawan atau Manajemen (Employee Stock Ownership Program, ESOP/Management Stock Ownership Program, MSOP). Total maksimum kepemilikan saham yang dapat dimiliki oleh manajemen sebesar 5\% (Wahyuningtyas, 2011).

Secara teoritis ketika kepemilikan manajerial tinggi, maka insentif terhadap kemungkinan terjadinya perilaku opportunistik manajer akan menurun. Dengan semakin tingginya kepemilikan manajerial permasalahan keagenan diasumsikan akan semakin berkurang. Kepemilikan manajerial ini

diukur dengan proporsi saham yang dimiliki perusahaan pada akhir tahun dan dinyatakan dalam presentase. Pengukuran presentase dihitung dari jumlah saham yang dimilki manajer dibagi dengan jumlah saham beredar. (Siallagan dan Machfoed, 2006); Febriani H.A. dan Murni S.(2014).

Kualitas laba yang dilaporkan dapat dipengaruhi oleh kepemilikan saham manajerial. Tekanan dari pasar modal menyebabkan perusahaan dengan kepemilikan manajerial yang rendah akan memilih metode akuntansi yang meningkatkan laba yang dilaporkan yang sebenarnya tidak mencerminkan keadaan ekonomi dari perusahaan yang bersangkutan (Boediono, 2005); Oktorina Megawati, L.K.W., (2015)

Tidak jauh berbeda dengan kepemilikan manajerial, kepemilikan institusi juga merupakan perwujudan dari prinsip GCG yaitu transparasi dimana dimaksudkan dengan kepemilikan institusi diluar perusahaan yang besar akan menyebabkan pihak luar perusahaan melakukan pengawasan dengan ketat terhadap pengelolaan oleh manajemen yang mengakibatkan manajemen dituntut untuk lebih meningkatkan kinerja perusahaan sehingga manajemen harus melakukan pengelolaan dengan transparan. (Herawaty, 2007)

Kepemilikan institusional memiliki kemampuan untuk mengurangi insentif para manajer yang mementingkan kepentingan diri sendiri melalui tingkat pengawasan yang intensif. Kepemilikan institusional dapat menekan kecenderungan manajemen untuk memanfaatkan discretionary dalam laporan keuangan sehingga memberikan kualitas laba yang dilaporkan. (Boediono, 2005)

Kepemilikan institusional adalah bagian dari saham perusahaaan yang dimiliki oleh investor institusi, seperti perusahaan asuransi, institusi keuangan (bank, perusahaan keuangan, kredit), dana pensiun, investment banking, dan perusahaan lainnya yang terkait dengan 
kategori tersebut (Yang et al., 2009; dalam Dian Agustia.,2013). Chew dan Gillan (2009:176) dalam Agustia (2013) menjelaskan bahwa terdapat dua jenis investor institusional, yaitu investor institusional sebagaitransient investors (pemilik sementara perusahaan) dan investor institusional sebagai sophisticated investors.

Boediono (2005), Mitra Santanu, Hossain Mahmud, (2011), menemukan bukti bahwa kepemilikan institusional mempunyai pengaruh yang positif terhadap kualitas laba. Artinya semakin tinggi kepemilikan institusional, maka laba akan semakin berkualitas. Kepemilikan institusional yang tinggi akan meningkatkan pengelolaan laba. Jika pengelolaan laba yang dilakukan perusahaan bersifat oportunis maka kepemilikan institusional yang tinggi akan mengurangi kemungkinan terjadinya manajemen laba, berkurangnyamanajemen laba akan meningkatkan kualitas laba yang di hasilkan oleh perusahaan.

Kepemilikan institusional adalah jumlah persentase hak suara yang dimiliki oleh institusi. Dalam penelitian ini diukur dengan menggunakan indikator persentase jumlah saham yang dimiliki institusi dari seluruh modal saham yang beredar (Beiner et al, 2003).

Komite Audit bertugas membantu dewan komisaris untuk memastikan bahwa (Bapepam-LK, 2010):Laporan keuangan disajikan secara wajar sesuai dengan prinsip akuntansi yang berlaku umum, Struktur pengendalian internal perusahaan dilaksanakan dengan baik, Pelaksanaan audit internal maupun eksternal dilaksanakan sesuai dengan standar audit yang berlaku, danTindak lanjut temuan hasil audit dilaksanakan oleh manajemen.

Komite Audit mempunyai peran yang sangat penting dan strategis dalam hal memelihara kredibilitas proses penyusunan laporan keuangan seperti halnya menjaga terciptanya sistem pengawasan perusahaan yang memadai, serta dilaksanakannya Good Corporate Governance. Dengan berjalannya fungsi komite audit secara efektif, maka kontrol terhadap perusahaan akan lebih baik, sehingga konflik keagenan yang terjadi akibat keinginan manajemen untuk meningkatkan kesejahteraannya dapat diminimalisasi (Rachmawati dan Triatmoko, 2007).

Keberadaan komite audit diharapkan dapat mengurangi sifat opportunistic manajemen yang melakukan manajemen laba dengan cara mengawasi laporan keuangan dan melakukan pengawasan pada audit eksternal (Siallagan dan Machfoedz, 2006); Mitra Santanu, H.M. (2011).

Berdasarkan Surat Edaran BEJ, SE-008/BEJ/12-2001, Komite audit sekurang-kurangnya terdiri atas tiga orang anggota, seorang diantaranya merupakan komisaris independen yang sekaligus merangkap sebagai ketua komite audit, sedangkan anggota lainnya merupakan pihak eksternal yang independen, di mana setidaknya satu di antaranya memiliki kemampuan di bidang akuntansi dan ataukeuangan. Komite audit diukur dengan jumlah anggota komite audit. (Susilowati et. al. 2011) Liang C. Hsin Yu, Chen, I-Ju, Chen, ShengSyan, (2016)

Laba merupakan indikator yang dapat digunakan untuk mengukur kinerja operasional perusahaan. Informasi tentang laba mengukur keberhasilan atau kegagalan bisnis dalam mencapai tujuan operasi yang ditetapkan. Kualitas laba dapat diindikasikan sebagai kemampuan informasi laba memberikan respon kepada pasar. Dengan kata lain, laba yang dilaporkan memiliki kekuatan respon(Parawiyati, 1996); Oktorina Megawati, L. K.W., (2015) Kuatnya reaksi pasar terhadap informasi laba yang tercermin dari tingginya Earnings Response Coefficients (ERC) menunjukkan laba yang dilaporkan berkualitas (Boediono, 
2005).ERC mengukur seberapa besar return saham dalam merespon angka laba yang dilaporkan oleh perusahaan yang mengeluarkan sekuritas tersebut. Dengan kata lain ERC adalah reaksi atas laba yang diumumkan (published) oleh perusahaan.(Jung, 1991)

Kualitas laba adalah penilaian sejauh mana laba sebuah perusahan dapat diperoleh berulang ulang, dapat dikendalikan, dan laik bank (memenuhi syarat untuk mengajukan kredit atau pinjaman pada bank), kualitas laba juga mengakui fakta bahwa dampak ekonomi transaksi yang terjadi akan beragam diantara perusahaan sebagai fungsi dari karakter dasar bisnis dan secara beragam dirumuskan sebagai tingkat laba yang menunjukkan dampak ekonomi pokoknya lebih baik dalam memperkirakan arus kas atau dapat diramalkan (Paulus, 2012). Laba yang berkualitas merupakan laba yang dapat menunjukkan informasi yang sebenarnya mengenai kinerja operasional perusahaan, sehingga tidak menyesatkan bagi pemakai laporan keuangan dalam mengambil keputusan. Informasi tentang laba seharusnya dapat dijadikan ukuran mengenai keberhasilan atau kegagalan bisnis dalam mencapai tujuan operasi yang ditetapkan suatu perusahaan. Selain itu laba juga dapat dipergunakan untuk memperkirakan keberlangsungan perusahaan di masa mendatang.(Siallagan dan Machfoed, 2006).

Menurut Fendi (2011), Fibriana, Enggar V. (2013). Kualitas laba perusahaan merupakan salah satu informasi penting yang tersedia untuk publik dan dapat digunakan investor untuk menilai perusahaan. Rendahnya kualitas laba akan dapat membuat kesalahan pembuatan keputusan para pemakainya seperti investor dan kreditor, sehingga nilai perusahaan akan berkurang.

Menurut Andri dan Hanung (2007) dalam Nica Febrina (2010:5) nilai perusahaan adalah nilai jual perusahaan atau nilai tumbuh bagi pemegang saham, nilai perusahaan akan tercermin dari harga pasar sahamnya. Nilai perusahaan menurut Rika dan Islahudin (2008:7) didefinisikan sebagai nilai pasar. Nilai perusahaan dapat memberikan kemakmuran pemegang saham secara maksimum apabila harga saham perusahaan meningkat. Semakin tinggi harga saham, maka makin tinggi kemakmuran pemegang saham. Untuk mencapai nilai perusahaan umumnya para pemodal menyerahkan pengelolaannya kepada para profesional. Para profesional diposisikan sebagai manajer ataupun komisaris.

Nilai perusahaan merupakan persepsi investor terhadap perusahaan, yang sering dikaitkan dengan harga saham. Harga saham yang tinggi membuat nilai perusahaan juga tinggi. Tujuan utama perusahaan menurut theory of the firm adalah untuk memaksimumkan kekayaan atau nilai perusahaan (value of the firm) dalam Salvatore(2005); Liang C. Hsin Yu, Chen, I - Ju, Chen, Sheng-Syan, (2016)

Memaksimalkan nilai perusahaan sangat penting artinya bagi suatu perusahaan, karena dengan memaksimalkan nilai perusahaan berarti juga memaksimalkan kemakmuran pemegang saham yang merupakan tujuan utama perusahaan. Menurut Husnan (2000) nilai perusahaan merupakan harga yang bersedia dibayar oleh calon pembeli apabila perusahaan tersebut dijual. Sedangkan menurut Keown (2004) nilai perusahaan merupakan nilai pasar atas surat berharga hutang dan ekuitas perusahaan yang beredar.

Nilai perusahaan merupakan persepsi investor terhadap tingkat keberhasilan perusahaan yang sering dikaitkan dengan harga saham. Nilai Perusahaan diukur dengan menggunakan PBV (Price Book Value) atau sering disebut juga Market to book Ratio (Atmaja, 2008). 
Perhitungan PBV sama dengan harga pasar per lembar saham dibagi dengan nilai buku per lembar saham.

Siallagan dan Machfoedz (2006), Fibriana, Enggar V. (2013). mengungkapkan bahwa semakin besar kepemilikan manajerial maka nilai perusahaan semakin rendah. Komite audit secara positif dan signfikan mempengaruhi nilai perusahaan. Menurut Kawatu (2005) menunjukkan bahwa mekanisme corporate governance secara positif mempengaruhi nilai perusahaan

Menurut Siallagan dan Machfoedz (2006), kualitas laba bukan variabel mediasi antara corporate governance dan nilai perusahaan. Karena nilai koefisien beta variabel independen mengalami kenaikan, sedangkan persyaratan untuk memunculkan variabel mediasi adalah dengan adanya penurunan nilai koefisien beta variabel independen baik signifikan ataupun tidak. Hipotesis dalam penelitian ini dirumuskan: "Kualitas laba merupakan variabel yang mediasi antara Kepemilikan manajerial, kepemilikan institusional, komite audit dengan nilai perusahaan.

\section{METODE PENELITIAN}

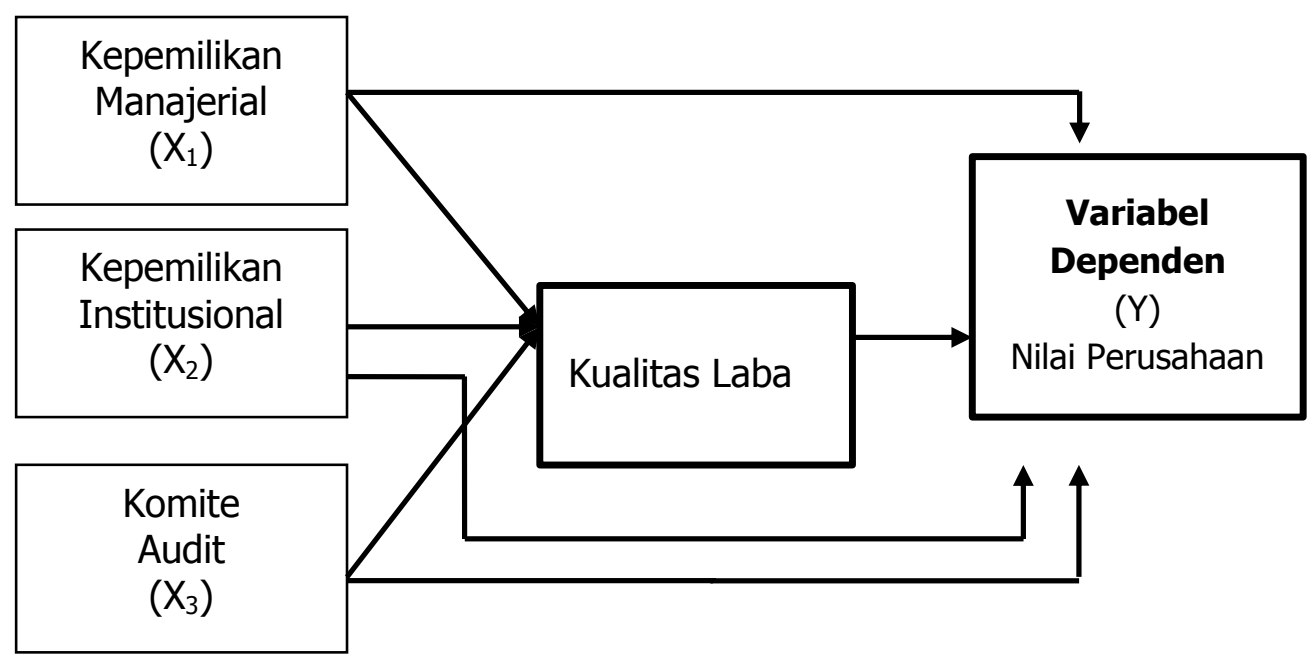

Gambar 1.Model Penelitian

Keterangan:

Dalam penelitian ini variabel independen yang digunakan adalah Kepemilikan manajerial (X1), Kepemilikan Institusional (X2), Komite Audit (X3), Kualitas Laba sebagai perantara (Z), dan variabel dependen Nilai Perusahaan (Y).

Dari kerangka pikir diatas peneliti menguji, mekanisme goodcorporate governance berpengaruh terhadap kualitas laba, dan good corporate governance mempengaruhi nilai perusahaan. Dan Kualitas laba menjadi mediasi antara good corporate governance dan nilai perusahaan.

Jenis populasi yang digunakan dalam penelitian ini adalah perusahaan manufaktur yang terdaftar di Bursa Efek Indonesia (BEI). Metode pengambilan sampel yang digunakan dalam penelitian ini adalah purposive sampling, yaitu penentuan sampel dengan menggunakan kriteria tertentu yang telah dibuat peneliti terhadap obyek sesuai dengan tujuan sampel penelitian. 
Kriteria perusahaan yang dijadikan sampel penelitian yaitu :

a. Perusahaan Manufaktur yang terdaftar di Bursa Efek Indonesia (BEI) pada periode 31 Desember 2012 - Desember 2014

b. Perusahaan Manufaktur yang menerbitkan Laporan Keuangan Tahunan dengan periode berakhir 31 Desember selama tahun 2012 - 2014

c. Laporan Keuangan yang disajikan dalam rupiah

d. Perusahaan yang memiliki data mengenai kepemilkian manajerial, kepemilikan institusional dan komite audit. Berdasarkan pesyaratan tersebut Jumlah Perusahaan yang menjadi sampel 34 unit

Dalam penulisan ini jenis data yang digunakan adalah data sekunder. Data sekunder merupakan sumber data penelitian yang diperoleh peneliti secara tidak langsung melalui media perantara (Nur Indriantoro dan Bambang Supomo, 2002:147) . Data sekunder yang digunakan merupakan data laporan tahunan perusahaan manufaktur tahun 2012-2014. Data diperoleh dari Indonesian Capital Market Directory (ICMD), annual report yang didapat melalui pojok Bursa Efek Indonesia (BEI)www.idx.co.id, Metode pengumpulan data dilakukan dengan metode dokumentasi yaitu pengumpulan data yang dilakukan dengan cara mencatat data dari laporan - laporan, catatan - catatan, dan arsip - arsip yang ada di beberapa sumber seperti perpustakan FE dan MM UNS, internet, dan sumber - sumber lain yang relevan dengan data yang dibutuhkan.

Metode pengumpulan data yang digunakan dalam penelitian ini adalah studi kepustakaan, yaitu data diperoleh dari beberapa literatur yang berkaitan dengan masalah yang sedang diteliti, penelusuran data ini dilakukan dengan cara:

a. Penelusuran secara manual untuk data dalam format kertas hasil cetakan. Data yang disajikan dalam format kertas hasil cetakan yang antara lain berupa jurnal, buku, skripsi dan thesis.

b. Penelusuran dengan menggunakan komputer untuk data dalam format elektronik. Data yang disajikan dalam format elektronik ini antara lainberupa laporan keuangan, katalog perpustakaan, laporan-laporan BEI, dan situs internet lainnya.

\section{VARIABEL DAN INDIKATOR PENELITIAN}

Sesuai dengan kerangka pemikiran dan pengajuan hipotesis diatas, maka hipotesis akan diuji dengan tiga persamaan regresi yang berbeda, yaitu :

$\begin{array}{ll}\mathrm{ERC}=\cdot 0+\cdot 1 \mathrm{KM}+\cdot 1 \mathrm{KI}++\cdot 1 \mathrm{KA}+1 & \text { Persamaan Regresi } 1 \\ \mathrm{NP}=\beta 0+\mathrm{ERC}+\beta 1 \mathrm{KM} 1+\beta 2 \mathrm{KI} 1+\beta 3 \mathrm{KA} 1+\varepsilon 2 & \text { Persamaan Regresi } 2\end{array}$

Keterangan :

$\mathrm{ERC}+$ Kandungan informasi dalam laba (slope $\cdot$ ) yang diukur dengan cara meregres antara cumulative abnormal return (CAR) dengan unexpected earning (UE) dan return

$\mathrm{NP}=$ Nilai perusahaan

$\mathrm{KM} \quad=\quad$ Kepemilikan manajerial perusahaan $\mathrm{i}$ pada periode $\mathrm{t}$

$\mathrm{KI}=$ Kepemilikan institusional perusahaan $\mathrm{i}$ pada periode $\mathrm{t}$

$\mathrm{KA}=$ Komite audit perusahaan $\mathrm{i}$ pada periode tTabel 1 . Operasional Variabel Penelitian 


\begin{tabular}{|c|c|c|}
\hline Variabel & Indikator & Alat Ukur \\
\hline $\begin{array}{l}\text { Kepemilikan } \\
\text { Manajerial (KI) }\end{array}$ & $\begin{array}{l}\text { persentase jumlah saham } \\
\text { yang dimiliki pihak } \\
\text { manajemen dari seluruh } \\
\text { modal saham perusahaan } \\
\text { yang beredar }\end{array}$ & $\begin{array}{l}\text { Jumlah saham yang } \\
\text { dimiliki manajer dibagi } \\
\text { jumlah saham beredar } \\
\text { kali } 100 \%\end{array}$ \\
\hline $\begin{array}{l}\text { Kepemilikan } \\
\text { Institusional (KI) }\end{array}$ & $\begin{array}{l}\text { persentase jumlah saham } \\
\text { yang dimiliki pihak } \\
\text { institusional dari seluruh } \\
\text { modal saham } \\
\text { perusahaan yang beredar }\end{array}$ & $\begin{array}{l}\text { Jumlah saham yang } \\
\text { dimiliki Institusi dibagi } \\
\text { jumlah saham beredar } \\
\text { kali } 100 \%\end{array}$ \\
\hline Komite Audit (KA) & Ada atau tidak komite audit & $\begin{array}{l}\text { jumlah anggota komite } \\
\text { audit }\end{array}$ \\
\hline Kualitas Laba (ERC) & $\begin{array}{l}\text { ERC (Earning Respon } \\
\text { Coefficient) }\end{array}$ & Regresi antara AR dan UE \\
\hline $\begin{array}{l}\text { Nilai Perusahaan } \\
\text { (NP) }\end{array}$ & Price Book Value & $\begin{array}{l}\text { PBV = Harga Pasar per } \\
\text { Lembar Saham dibagi } \\
\text { (Nilai Buku per Lembar } \\
\text { Saham) }\end{array}$ \\
\hline
\end{tabular}

Sumber: Data diolah 2016

\section{HASIL PENELITIAN}

Analisis regresi berganda dilakukan untuk membuktikan adanya pengaruh variabel independen terhadap variabel dependen. Pada penelitian ini pengujian regresi linier berganda digunakan untuk mengetahui pengaruh good corporate governance yang terdiri dari kepemilikan manajerial, kepemilikian institusional, komite audit terhadap nilai perusahaan dengan kualitas laba sebagai variabel mediasi pada perusahaan manufaktur yang terdaftar di BEI tahun 2012 - 2014.

Model persamaan regresi yang digunakan sebagai berikut :

a. Persamaan Regresi $1: \mathrm{ERC}=\beta 0+\beta 1 \mathrm{KM} 1+\beta 2 \mathrm{KI} 1+\beta 3 \mathrm{KA} 1+\varepsilon 1$

b. Persamaan Regresi 2 : NP $=\beta 0+E R C+\beta 1 K M 1+\beta 2 K I 1+\beta 3 K A 1+\varepsilon 2$

Keterangan :

ERC : Kandungan informasi dalam laba (slope a) yang diukur dengan cara meregres antara cumulstive abnormal return (CAR) dengan unexpected earning (UE) dan return.

B : Koefisien regresi variabel inpenden

NP : Nilai Perusahaan

KM1 : Kepemilikan manajerial perusahaan i pada periode $t$

KI1 : Kepemilikan Institusional perusahaan I pada periode $t$

KA1 : Komite audit perusahaan i pada periode $t$

E : error term

Berdasarkan perhitungan dengan persamaan diatas, maka diperoleh hasil sebagai berikut : 
Tabel 2. Hasil Pengujian Regresi Model

\begin{tabular}{lcccc}
\hline \multicolumn{1}{c}{$\begin{array}{c}\text { Variabel } \\
\text { Regression* }\end{array}$} & Coefficient & Nilai t & Nilai F & Sig \\
(constant) & 603.967 & 8.322 & & $0.103^{a}$ \\
KM (X1) & 0.283 & 0.187 & 0.000 \\
KI (X2) & 0.315 & 0.427 & 0.852 \\
KA (X3) & -20.952 & -2.098 & 0.671 \\
Square & 0.061 & & 0.038 \\
Adj Square & 0.032 & & 106.998 \\
a. Predictor : (constant),KM, KI, Komite Audit \\
b. Variabel Dependen : ERC(CAR)
\end{tabular}

Tabel 3 Hasil Pengujian Regresi Model 2

\begin{tabular}{lcccc}
\hline $\begin{array}{c}\text { Variabel } \\
\text { Regression* }\end{array}$ & Coefficient & Nilai t & $\begin{array}{c}\text { Nilai F } \\
5.521\end{array}$ & $\begin{array}{c}\text { Sig } \\
0.000 \mathrm{a}\end{array}$ \\
\hline \multicolumn{1}{c}{ (Constant) } & 740986.688 & 2.398 & & 0.018 \\
$\mathrm{KM}(\mathrm{X} 1)$ & -9812.303 & -1.991 & 0.049 \\
$\mathrm{KI}(\mathrm{X} 2)$ & -5801.854 & -2.411 & 0.018 \\
$\mathrm{KA}(\mathrm{X} 3)$ & 57044.146 & 1.715 & 0.090 \\
$\mathrm{ERC}(\mathrm{Z})$ & -602.071 & -1.829 & 0.070 \\
R Square & & & 0.185 \\
Adj R square & & & 0.152 \\
\hline
\end{tabular}

$\mathrm{ERC}=603,967+0.283 \times 1+0.315 \times 2-20.952 \times 3+\varepsilon$

Berdasarkan persamaan regresi model1, dapat dibuat interprestasi sebagai berikut:

1. Nilai konstan untuk persamaan regresi adalah 603,967 dengan parameter positif. Hal ini menunjukkan bahwa dengan adanya good corporate governance dalam hal ini kepemilikan manejerial, kepemilikan institusional dan komite audit, maka tingkat kualitas laba pada perusahaan manufaktur yang terdaftar di BEI akan mengalami kenaikan sebesar 603,967

2. Nilai koefisien $\beta 1$ untuk variabel kepemilikan manajerial sebesar 0,283 menunjukkan variabel kepemilikan manajerial mempunyai pengaruh positif terhadap variabel dependen dalam hal ini kualitas laba yang diproksikan dengan ERC (Earning Respon Coeficient). Apabila kepemilikan manajerial bertambah 1 satuan maka akan berdampak pada kenaikan kualitas laba sebesar 0,283 satuan dengan asumsi variabel yang lain 0 .

3. Nilai koefisien $\beta 2$ untuk variabel kepemilikan institusional sebesar 0,315 dengan parameter positif. Hal ini menunjukkan bahwa kepemilikan institusional memiliki pengaruh positif terhadap kualitas laba. Apabila kepemilikan institusional bertambah 1 satuan maka kualitas laba akan meningkat sebesar 0,315.

4. Koefisien $\beta 3$ untuk komite audit sebesar $-20,952$ yang berarti komite audit mempunyai pengaruh negatif terhadap kualitas laba yang diproksikan dengan ERC(Earning Respon Coeficient). Apabila komite audit bertambah 1 satuan akan meningkatkan kualitas laba 
sebesar -20,952 dan sebaliknya bila komite audit berkurang 1 satuan akan mengurangi kualitas laba sebesar -20,952.

Selanjutnya dari Tabel 4 yang merupakan pengujian regresi linier berganda dapat dibuat persamaan sebagai berikut : NP $=740986,688-9812,303 X 1-5801,854 X 2+57044,146$ X3 602,0712

Berdasarkan persamaan regresi model 2, dapat dibuat interprestasi sebagai berikut:

1. Nilai konstan untuk persamaan regresi adalah 740986,688 dengan parameter positif. Menunjukkan apabila good corporate governance dalam hal ini kepemilikan manajerial, kepemilikan institusional, komite audit dan kualitas laba sebagai variabel independen bernilai nol, maka nilai perusahaan perusahaan manufaktur yang terdaftar di BEI adalah 740986,688

2. Koefisien $\beta 1$ untuk variabel kepemilikan manajerial sebesar - 9812,303 yang berarti kepemilikan manajerial mempunyai pengaruh negatif terhadap nilai perusahaan. Apabila kepemilikan manajerial bertambah 1 satuan akan meningkatkan nilai perusahaan sebesar -9812,303 dan sebaliknya bila kepemilikan manajerial berkurang 1 satuan akan mengurangi nilai perusahaan sebesar $-9812,303$

3. Koefisien $\beta 2$ untuk variabel kepemilikan institusional sebesar $-5801,854$ yang berarti kepemilikan institusional mempunyai pengaruh negatif terhadap nilai perusahaan. Apabila kepemilikan institusional bertambah 1 satuan akan meningkatkan nilai perusahaan sebesar $-5801,854$ dan sebaliknya

4. Koefisien $\beta 3$ untuk variabel komite audit sebesar 57044,146 yang berarti komite audit mempunyai pengaruh positif. Apabila komite audit bertambah 1 satuan maka nilai perusahaan akan meningkat sebesar 57044,146.

Selanjutnya, dilakukan pengujian path analysis. Pengujian ini dilakukan untuk mengetahui pengaruh variabel independen terhadap variabel dependen melalui variabel mediasi. Tabel 5 berikut ini merupakan hasil pengujian dengan menggunakan SPSS 19.0:

Tabel 5. Variabel KM, KI, KA Terhadap Kualitas Laba

\begin{tabular}{|c|c|c|c|c|}
\hline $\begin{array}{l}\text { Variabel } \\
\text { Regression* }\end{array}$ & Coefficient & Nilai $t$ & $\begin{array}{c}\text { Nilai F } \\
2.117\end{array}$ & $\begin{array}{l}\text { Sig. } \\
0.103 a\end{array}$ \\
\hline (Constant) & 603.967 & 8.322 & & 0.000 \\
\hline $\mathrm{KM}(\mathrm{X} 1)$ & 0.283 & 0.187 & & 0.852 \\
\hline $\mathrm{KI}(\mathrm{X} 2)$ & 0.315 & 0.427 & & 0.671 \\
\hline $\mathrm{KA}(\mathrm{X} 3)$ & -20.952 & -2.098 & & 0.038 \\
\hline $\begin{array}{l}\text { R Square } \\
\text { Adj R Square }\end{array}$ & 0.061 & 0.032 & & \\
\hline
\end{tabular}

a. Predictors : (Constant), Kepemilikan Manajerial, Kepemilikan

Institusional, Komite Audit

b. Dependen Variabel: Kualitas

Sumber : Data sekunder diolah, 2015 
Tabel 6. Variabel KM, KI, KA, Kualitas Laba Terhadap Nilai Perusahaan

\begin{tabular}{|c|c|c|c|c|}
\hline $\begin{array}{l}\text { Variabel } \\
\text { Regression* }\end{array}$ & Coefficient & Nilai t & $\begin{array}{c}\text { Nilai F } \\
5.521\end{array}$ & $\begin{array}{l}\text { Sig. } \\
0.000^{a}\end{array}$ \\
\hline (Constant) & 740986.688 & 2.398 & & 0.018 \\
\hline $\mathrm{KM}(\mathrm{X} 1)$ & -9812.303 & -1.991 & & 0.049 \\
\hline $\mathrm{KI}(\mathrm{X} 2)$ & -5801.854 & -2.411 & & 0.018 \\
\hline$K A(X 3)$ & 57044.146 & 1.715 & & 0.090 \\
\hline ERC /CAR (Z) & -602.071 & -1.829 & & 0.070 \\
\hline
\end{tabular}

\section{Adj R Square}

\subsection{2}

a. Predictors : (Constant), Kepemilikan Manajerial, Kepemilikan Institusional, Komite Audit, ERC

b. Dependen Variabel : Nilai Perusah

Sumber : Data sekunder diolah, 2016

Untuk mengetahui secara pasti bahwa kualitas laba dapat menjadi mediasi antara Kepemilikan manajerial, kepemilikan institusional, komite audit dengan nilai perusahaan, perlu dilakukan penghitungan sebagai berikut :

a. Koefisien Kepemilikan manajerial terhadap kualitas laba $\mathbf{X}$ koefisien kualitas laba terhadap nilai perusahaan < (koefisien kepemilikan manajerial terhadap nilai perusahaan)2

b. Koefisien kepemilikan institusional terhadap kualitas laba X koefisien kualitas laba terhadap nilai perusahaan < (koefisien kepemilikan institusi terhadap nilai perusahaan)2

c. Koefisien komite audit terhadap kualitas laba $\mathrm{X}$ koefisien kualitas laba terhadap nilai perusahaan < (koefisien komite audit terhadap nilai perusahaan)2

Hasil pengujian membandingkan nilai standardized coefficient persamaan regresi 1 dengan standardized coefficient persamaan regresi 2. Dimana yang memilki nilai lebih besar maka pengaruh itulah yang menyatakan hubungan yang sebenarnya.

\section{PENGUJIAN ANALISIS JALUR}

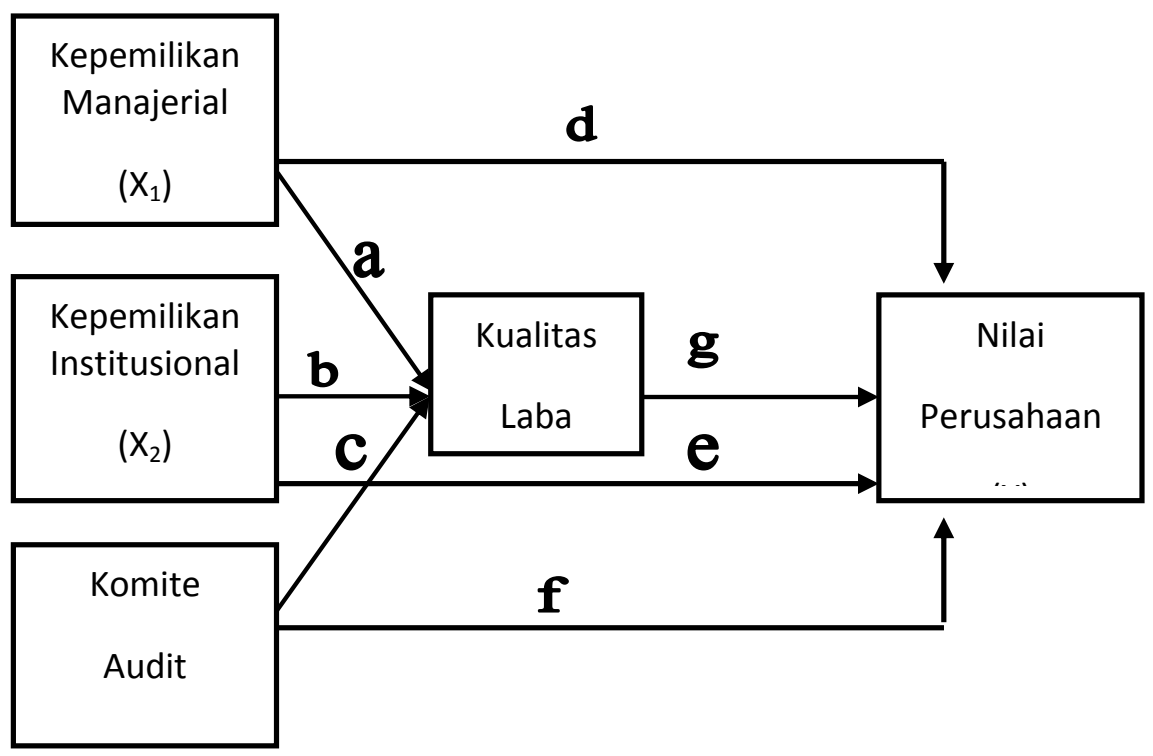

Gb.2 Analisis Jalur 
Hasil Perhitungan Kualitas laba sebagai mediasi :

a) $\quad \mathrm{a} * \mathrm{~g}<\mathrm{d} 2=(0,028) \times(-0,173)<(-0,275) 2=-0,004<0,075$

b) $\quad$ b*g $<2=(0,060) \times(-0,173)<(-0,317) 2=-0,010<0,100$

c) $\quad c^{*} \mathrm{~g}>\mathrm{f} 2=(-0,231) \times(-0,173)<(0,181) 2=0,039>0,032$

Hasil pengujian hipoteis dari variabel, kualitas laba sebagai variabel mediasi antara Kepemilikan manajerial, kepemilikan institusional, komite audit dengan nilai perusahaan.

Dari uji analisys path menghasilkan nilai beta koefisien variabel pada kepemilikan manajerial sebesar -0,004 (hasil perkalian 0,028 dengan -0,173) yang mengindikasikan bahwa kepemilikan manajerial melalui kualitas laba memberikan dampak -0,004 terhadap nilai perusahaan. Dibandingkan dengan kepemilikan manajerial secara langsung mempengaruhi nilai perusahaan sebesar 0,075 (dua kali 0,275).

Nilai beta koefisien variabel pada kepemilikan institusional sebesar $-0,010$ (hasil perkalian 0 , 060 dengan $-0,173$ ) yang mengindikasikan bahwa kepemilikan institusional melalui kualitas laba memberikan dampak 0,010 terhadap nilai perusahaan. Dibandingkan dengan kepemilikan institusional secara langsung mempengaruhi nilai perusahaan sebesar 0,100.

Nilai beta koefisien variabel pada komite audit sebesar 0,039 (hasil perkalian antara -0,231 dengan $-0,173$ ) yang mengindikasikan bahwa komite audit melalui kualitas laba memberikan dampak 0,039 terhadap nilai perusahaan. Dibandingkan dengan komite audit secara langsung mempengaruhi nilai perusahaan sebesar 0,032.

Dari perhitungan tersebut, dapat dilihat bahwa dengan melibatkan kualitas laba sebagai mediasi, hanya pada komite audit saja yang menghasilkan angka koefisien yang lebih tinggi sedangkan kepemilikan menejerial dan institusi lebih rendah. Jadi dapat di simpulkan Kualitas laba hanya memediasi pengaruh komite audit pada nilai peusahaan. Kualitas laba tidak memediasi kepemilikan managerial dan institusi pada nilai perusahaan

\section{PEMBAHASAN}

Hasil penelitian ini menyatakan Kualitas laba hanya memediasi pengaruh komite audit pada nilai peusahaan. Kualitas laba tidak memediasi kepemilikan managerial dan institusional pada nilai perusahaan. Komite audit yang baik akan meningkatkaan nilai perusahaan dan akan semakin baik lagi bila kualitas labanya baik. Hal ini sangat rasional karena laba mencerminkan nilai perusahaan. Nilai perusahaan di tentukan laba yang diperoleh dari perusahaan dari waktu ke waktu. Kepemilikan manajerial dan institusional tidak dimediasi oleh kualitas laba. Kepemilikan sering tidak mempengaruhi kualitas laba. Banyak sedikitnya kepemilikan manajerial dan institusional tidak mempengaruhi nilai perusahaan. Keadaan walaupun kepemilikan manajerial dan instittusional baik tetapi kualitas labanya ttidak baik maka nilai perusahaan tetap tidak baik. Hal ini merupakan keadaan yang rasional.

Hasil ini mendekati penelitian dari Siallagan dan Machfoedz (2006), Fibriana, Enggar V. (2013). mengungkapkan bahwa semakin besar kepemilikan manajerial maka nilai perusahaan semakin rendah. Komite audit secara positif dan signfikan mempengaruhi nilai perusahaan. Menurut Kawatu (2005) menunjukkan bahwa mekanisme corporate governance (kepemilikan manajerial, institusional dan komite audit) secara positif mempengaruhi nilai perusahaan

Baron dan Kenny (1986) perubahan koefisien beta yang memenuhi syarat untuk memunculkan variabel mediasi adalah koefisien beta yang mengalami penurunan, baik 
menjadi signifikan maupun tidak signifikan. Pada pengaruh good corporate governcance yang diproksikan dengan kepemilikan manajerial, kepemilikan isntitusional dan komite audit kepemilikan manajerial melalui kualitas laba mengalami penurunan sebesar -0,004 jika dibandingkan tanpa melalui kualitas laba. Kepemilikan institusional melalui kualitas laba juga mengalami penurunan sebesar -0,010 jika dibandingkan tanpa melalui kualitas laba. Komite audit mengalai kenaikan dengan adanya kualitas laba sebesar 0,039 jika dibandingkan tanpa melalui kualitas laba.

Dari path analisys dapat diketahui dengan adanya kualitas laba sebagai variabel mediasi antara good corporate governance dan nilai perusahaan. Pada komite audit saja yang mengalami peningkatan sebesar 0,7\%. Hal ini disebabkan pada perhitungan regresi untuk ERC (Earning Respon Coeficient) yang menggunakan IHSG (Indeks Harga Saham Gabungan) sebagai dasar untuk mengetahui Abnormal Return pada perusahaan manufaktur yang listing di BEI pada periode 2012 - 2014 mengalami penurunan karena adanya regulasi dari The Fed yang akan menaikan suku bunga bank yang berdampak pada melemahnya nilai tukar rupiah terhadap dollar AS sehingga memberikan dampak buruk pada pasar modal di Indonesia khususnya pada perusahaan - perusahaan yang listing di BEI.

\section{KESIMPULAN}

Berdasarkan pengujian, pengolahan, dan analisis data yang dilakukan, maka dapat ditarik simpulan kualitas laba sebagai mediasi, hanya pada komite audit saja yang menghasilkan angka koefisien yang lebih tinggi sedangkan kepemilikan menejerial dan institusional lebih rendah. Jadi dapat di simpulkan Kualitas laba hanya memediasi pengaruh komite audit pada nilai peusahaan. Kualitas laba tidak memediasi kepemilikan managerial dan institusi pada nilai perusahaan

\section{SARAN PENELITIAN YANG AKAN DATANG}

Penelitian berikutnya dapat memperhatikan instrument penelitian yang digunakan untuk mengukur kualitas laba dalam Earning Response Coefficient (ERC) seperti kondisi IHSG dan pada nilai perusahaan menggunakan pengukur lain seperti Tobin-Q yang dimodifikasi menggunakan closing price (harga penutupan saham akhir tahun).

\section{DAFTAR PUSTAKA}

Barnhart, Scott and Stuart Rosenstein. (1998). Board Composition,Managerial Ownership and Firm Performance: An Empirical Analysis. The Financial Review, http://papers.sfm?abstract_id=127689.

Boediono, Gideon SB. (2005). Kualitas Laba: Studi Pengaruh Mekanisme Corporate Governance dan Dampak Manajemen Laba dengan Menggunakan Analisis Jalur. Simposium Nasional Akuntansi VIII Solo

Bellovary, J.L., Giacomino, D.E. \& Akers, M. D.(2005). Earnings quality: its time to measure and report. The CPA Journal, 75(11), 32-37.

Bursa Efek Jakarta. Kep-339/BEJ/07-2001 Ketentuan Umum Pencatatan Efek Di Bursa Efek dan Keanggotaan Bursa. http://www .jsx.co.id

Bushee, Brian, J.,(1998), The Influence of Institusional Investor on Myopic R\&D Investment Behavior.The Accounting ReviewVol 73 No. 3, pp. 305 
Dechow P. (2010). Understanding Earnings Quality: A Review of The Proxie, their determinants and their consequence.Journal of Accounting and Economics 50 (2010) Pages 344-40.

Eka, (2011). Pengaruh Penerapan Corporate Governance terhadap Kinerja Keuangan pada Industri Perbankan yang terdaftar di Bursa efek Indonesia (BEI) tahun 2006-2008. Skripsi S. Fakultas Ekonomi Universitas Diponegoro. Semarang.

Fama, Eugene F. (1978). The Effects of a Firm's Investment and Financing Decisions on the Welfare of Its Security Holders. The American Economic Review. 272-284

Febriani Hanna Amilia, Murni Sri (2014). Corporate Governance Structure and Internal Control Disclosure of Consumer Goods Firm in Indonesiajournal Abstract of Economic, Finance and Management Outlook.Vol. 2 no.12. Pp: 40

Fibriana, Enggar V. (2013). Pengaruh Corporate Goverance Terhadap Nilai Perusahaan, Kualitas laba sebagai variabel mediasi. Jurnal Ilmu dan Riset Akuntansi, Volume 1 Nomor 1.

Forum of Corporate Governance in Indonesia (FCGI). (2002). Peranan Dewan Komisaris dan Komite Audit dalam Pelaksanaan Corporate Governance (Tata Kelola Perusahaan).(http://www.fcgi.or.id), diakses 11 Mei 2015.

Ghozali, Imam. (2010). Aplikasi Analisis Multivariate dengan Program SPSS. Semarang: Badan Penerbit Universitas Diponegoro.

Harahap, Sofyan Syafri. (2007), Analisis Kritis atas Laporan Keuangan, PT Raja Grafindo, Jakarta.

Haruman, Tendy. (2008). Pengaruh Struktur Kepemilikan terhadap Keputusan Keuangan dan Nilai Perusahaan (Survei pada Perusahaan Manufaktur di PT. Bursa Efek Indonesia). Simposium Nasional Akuntansi XI. Pontianak.

Hastuti, Theresia Dwi. (2005). Hubungan Antara Good Corporate Governance dan Struktur Kepemilikan dengan Kinerja Keuangan.Simposium Nasional Akuntansi (SNA) VIII Solo.

Herawaty, Vinola. (2008). Peran Praktek Corporate Governnacesebagai variabel moderating dari Pengaruh Earning Management terhadap Nilai Perusahaan. Jurnal Keuangan Universitas Trisakti, Jakarta.

Jensen, Michael C. dan W. H. Meckling. (1976). Theory of The Firm: Managerial Behaviour, Agency Cost and Ownership Structure. http://papers.ssrn.com

Kaihatu, Thomas, S., 2006, Good Corporate Governance dan Penerapannya di Indonesia. Jurnal Manajemen dan Kewirausahaan, Vol. 8 No. 1, Hal 2

Kawatu, Freddy Semuel. (2009). Mekanisme Corporate Governance terhadap Nilai Perusahaan dengan Kualitas Laba sebagai Variabel Mediasi. Artikel Jurnal Keuangan dan Perbankan. Vol. 13, No.3, September 2009: 405-417.

Kusumaning, Linda; (2004). Analisis Pengaruh Proporsi Dewan Komisaris dan Keberadaan Komite Audit Terhadap Aktivitas Manajemen Laba Pada Perusahaan Publik di Indonesia, Tesis Universitas Gajah Mada.

Liang C. Hsin Yu, Chen, I - Ju, Chen, Sheng-Syan, (2016). Does corporate governance mitigate bank diversification discount? journal International Review of Economics \& Finance.Vol.45. pp. 129-143 
Midiastuty, Pratana Puspa dan Mas'ud Machfoedz.(2003). Analisis Hubungan Mekanisme Corporate Governance dan Indikasi Manajemen Laba.Simposium Nasional Akuntansi (SNA) VI Surabaya.

Mitra Santanu, Hossain Mahmud, (2011). Corporate governance attributes and remediation of internal control material weaknesses reported under SOX Section 404 journal Review of Accounting and Finance.Vol.: 10 no.1. pp: 5 - 29

Muid, Dul, (2009). "Pengaruh Mekanisme Corporate Governance Terhadap Kualitas Laba". Fokus Ekonomi, Volume No. 4.

OECD. (2005). Good Corporate Governance. Jakarta: PT Damar Mulia Pustaka.

Oktorina Megawati, Linda Kusumaning Wedari, (2015), An Empirical Investigation on Ownership Characteristics, Activities of the Audit Committee, and Audit Fees in Companies Listed on Indonesia Stock Exchange journal Applied Finance and Accounting.Vol 1 : 1.pp: 20-29

Rachmawati, Andri dan Hanung Triatmoko. (2007). Analisis Faktor-faktor yang Mempengaruhi Kualitas Laba dan Nilai Perusahaan. Artikel Simposium Nasional Akuntansi (SNA) X, Makasar

Rupilu, Wilsna. (2011)." Pengaruh Mekanisme Corporate Governance Terhadap Kualitas Laba dan Nilai Perusahaan pada Perusahaan Manufaktur yang Terdaftar di Bursa Efek Indonesia."Jurnal Akuntansi, Manajemen Bisnis dan Sektor Publik, Vol 8 No. 1 Hal $101-127$.

Ryan LaFond, Daniel W. Collins, and Ashbaugh-Skaife,H., (2006), The Effect of Corporate Governance on Firms'credit rating.Journal Accounting and Economics 42, pp. 203 243.

Setiawan, Wawan. (2006). Analisis Pengaruh Mekanisme Corporate Governance Terhadap Kualitas Laba. Jurnal Akuntansi dan Bisnis, Volume. No.2. Hal. 163-172.

Siallagan, Hamonangan dan Machfoedz, Mas'ud. (2006). "Mekanisme Corporate Governance, Kualitas Laba dan Nilai Perusahaan". Simposium Nasional Akuntansi IX : Universitas Andalas, 23-26 Agustus 2006. Padang.

Scott, William R., (2000). "Financial Accounting Theory." Second edition. Canada: Prentice Hall.

Suaryana, A. (2005) PengaruhKomite Audit terhadap Kualitas Laba. Working Paper SNA VIII. Solo, 15 - 16 September 2005.

Susanti, Angaheni Niken, Rahmawati dan Aryani. (2010). "Analisis Pengaruh Mekanisme Corporate Governance terhadap Nilai Perusahaan dengan Kualitas Laba sebagai variabel Mediasi pada Perusahaan Manufaktur yang terdaftar di Bursa Efek Indonesia 2004-2007" Artikel Simposium Nasional Keuangan I.

Teoh, S. H. dan Wong, T. J. (1993), "Perceived Auditor Quality and the Earnings Responses Coefficient". Journal Accounting Review. Vol. 66, No.2, hal. 346-366.

Wahyudi, U. dan Pawestri, H.P. (2011). Implikasi Struktur Kepemilikan terhadap Nilai Perusahaan: Dengan Keputusan Keuangan sebagai Variabel Mediasi. Artikel Simposium NasionalAkuntansi (SNA) IX, Padang.

Watts R. and J.L. Zimmerman. (1986). Positive Accounting Theory. New York: Prentice Hall. Wright, 1997; 
Wiratna Sujarweni, (2014), SPSS untuk Penelitian, Cetakan I, Yogyakarta: Pustaka Baru Press. 